\title{
European child and adolescent psychiatry-endorse the importance of prospective longitudinal study designs
}

\author{
Veit Roessner
}

Published online: 6 November 2012

(c) Springer-Verlag Berlin Heidelberg 2012

This current issue of European child and adolescent psychiatry (ECAP) presents a substantial number of relevant publications. More specifically, two studies on psychopathology present results from Korea [11, 18], one from Finland [19] and one from the Netherlands [20]. Over the years the methodological standards of studies published in ECAP have vastly improved, e.g., in sample size or by implementing a longitudinal design. The value of the latter as well as other methodological improvements has been highlighted by Sir Michael Rutter [16] in ECAP in his review "Child and adolescent psychiatry: past scientific achievements and challenges for the future". The present longitudinal study by Shin et al. [18] is a prime example of these aforementioned advancements. They conducted a baseline examination of parental ratings of 3,808 children aged 6.85 years using the Korean version of the child behavior checklist (K-CBCL). To identify the predictors of juvenile delinquent tendencies, they administered the Korean youth self-report (K-YSR) at the 6- to 8-year follow-up for at least 1,821 adolescents aged 13.75 years. This current issue also presents findings by Lee et al. [11] who investigated a large sample, i.e. a total of 4,899 Korean students aged 13-18 years by implementing several self-report forms of questionnaires to identify possible relationships between the Type D personality construct and other mental health measures. Type D personality is characterized by both normal and stable personality traits, negative affectivity (NA, the tendency to experience negative emotions), and social inhibition (SI, the tendency to

\section{Roessner ( $\square)$}

Department of Child and Adolescent Psychiatry,

University of Dresden Medical School,

Fetscherstrasse 74, D-01307 Dresden, Germany

e-mail: Veit.Roessner@uniklinikum-dresden.de inhibit expression of emotions). The authors concluded that the administered validated Korean version of the Type D Personality-14 scale (DS14) can be useful in a community mental health program designed for adolescents. Taking into consideration that validity and reliability of the DS14 have been verified in both European and Korean populations, this raises the question as to why the authors, as many others previously, did not conduct a cross-cultural study in an attempt to gain further insights regarding the Type D construct. This shortfall could be seen as a reflection of the small amount of available studies on crosscultural comparisons of psychopathology constructs. Nevertheless, exceptions can be found, also in this issue of ECAP. Veen et al. [21] compared mental health issues between incarcerated adolescents of Dutch and Moroccan origin. Their findings indicate that native Dutch adolescent offenders show higher levels of mental health problems than incarcerated adolescents with an ethnic minority (Moroccan) background. Meanwhile there exists an excellent basic list of steps to be taken to achieve valid assessment across cultures [15].

In a previous editorial, Hoekstra [8] highlighted the need for a long-term perspective in child and adolescent psychiatry. The current issue, but also previous issues of recent years, has presented a large increase in longitudinal studies $[1,2,5-7,9,22]$.

In addition to the welcome international orientation, ECAP also serves as a platform for innovative topics and findings which at times may seem somewhat "off the mainstream of research". In their present work, de Bruin et al. [3] report that the existence of finger print discordance, as a possible marker of prenatal instability, was associated with the occurrence of formal thought disorder in girls. Similarly, unique topics have been the decreased serum cholesterol levels in child and adolescent psychiatric 
inpatients who attempted suicide [14] or the association between atopic conditions and mental health problems indicating that adolescents with atopic conditions are at risk for mental health problems [12]. The latter has gained increased attention over the past month [17] highlighting the growing interest in innovative ways of thinking and research to progress our understanding of the etiopathophysiology of mental disorders also with the hope to find new approaches for developing better treatment alternatives.

Finally, ECAP also regularly publishes articles dealing with important issues of daily clinical work in child and adolescent psychiatry. This pursues two main goals: first to inform about the actual base of knowledge and second to provide impetus for more research in those fields. In the present issue, McNicholas [13] reviews some of the main issues with regard to adherence, cost implications of suboptimal adherence and suggests future directions. Previous articles dealt with often discussed questions that were handled very differently across the clinical centers, e.g., cardiological problems in patients with anorexia nervosa at different stages of weight recovery [10] or the management of adverse effects of medication for ADHD [4].

\section{References}

1. Carballo JJ, Baca-Garcia E, Blanco C, Perez-Rodriguez MM, Arriero MA, Artes-Rodriguez A, Rynn M, Shaffer D, Oquendo MA, Group for the Study of Evolution of D (2010) Stability of childhood anxiety disorder diagnoses: a follow-up naturalistic study in psychiatric care. Eur Child Adolesc Psychiatry 19:395-403

2. Chitsabesan P, Rothwell J, Kenning C, Law H, Carter L, Bailey S, Clark A (2012) Six years on: a prospective cohort study of male juvenile offenders in secure care. Eur Child Adolesc Psychiatry 21:339-347

3. de Bruin E, de Nijs PFA, Verhulst FC, Huizink AC (2012) The association between formal thought disorder and finger print asymmetry in children with a psychiatric disorder: an exploratory study. Eur Child Adolesc Psychiatry. doi:10.1007/s00787-0120309-2

4. Graham J, Banaschewski T, Buitelaar J, Coghill D, Danckaerts M, Dittmann RW, Dopfner M, Hamilton R, Hollis C, Holtmann M, Hulpke-Wette M, Lecendreux M, Rosenthal E, Rothenberger A, Santosh P, Sergeant J, Simonoff E, Sonuga-Barke E, Wong IC, Zuddas A, Steinhausen HC, Taylor E, European Guidelines G (2011) European guidelines on managing adverse effects of medication for ADHD. Eur Child Adolesc Psychiatry 20:17-37

5. Gyllenberg D, Sourander A, Niemela S, Helenius H, Sillanmaki L, Piha J, Kumpulainen K, Tamminen T, Moilanen I, Almqvist F (2010) Childhood predictors of later psychiatric hospital treatment: findings from the Finnish 1981 birth cohort study. Eur Child Adolesc Psychiatry 19:823-833

6. Hautmann C, Eichelberger I, Hanisch C, Pluck J, Walter D, Dopfner M (2010) The severely impaired do profit most: shortterm and long-term predictors of therapeutic change for a parent management training under routine care conditions for children with externalizing problem behavior. Eur Child Adolesc Psychiatry 19:419-430

7. Heikkila HK, Vaananen J, Helminen M, Frojd S, Marttunen M, Kaltiala-Heino R (2012) Involvement in bullying and suicidal ideation in middle adolescence: a 2-year follow-up study. Eur Child Adolesc Psychiatry [Epub ahead of print]

8. Hoekstra PJ (2010) The need for a long-term perspective in child and adolescent psychiatry. Eur Child Adolesc Psychiatry 19: 687-688

9. Hoekstra PJ, Lundervold AJ, Lie SA, Gillberg C, Plessen KJ (2012) Emotional development in children with tics: a longitudinal population-based study. Eur Child Adolesc Psychiatry. doi: 10.1007/s00787-012-0337-y

10. Kastner S, Salbach-Andrae H, Renneberg B, Pfeiffer E, Lehmkuhl U, Schmitz L (2012) Echocardiographic findings in adolescents with anorexia nervosa at beginning of treatment and after weight recovery. Eur Child Adolesc Psychiatry 21:15-21

11. Lee M-S, Lim HE, Ko Y-H, Han C, Kim Y-K, Yang J, Kim JJ, Lee JE, Cha JY, Lee H (2012) Characteristics of Type D personality in Korean adolescents. Eur Child Adolesc Psychiatry. doi:10.1007/s00787-012-0314-5

12. Lien L, Green K, Thoresen M, Bjertness E (2010) Atopic conditions and mental health problems: a 3-year follow-up study. Eur Child Adolesc Psychiatry 19:705-713

13. McNicholas F (2012) To Adhere or not, and what we can do to help. Eur Child Adolesc Psychiatry. doi:10.1007/s00787-0120304-7

14. Plana T, Gracia R, Mendez I, Pintor L, Lazaro L, Castro-Fornieles J (2010) Total serum cholesterol levels and suicide attempts in child and adolescent psychiatric inpatients. Eur Child Adolesc Psychiatry 19:615-619

15. Prince M (2008) Measurement validity in cross-cultural comparative research. Epidemiol Psichiatr Soc 17:211-220

16. Rutter M (2010) Child and adolescent psychiatry: past scientific achievements and challenges for the future. Eur Child Adolesc Psychiatry 19:689-703

17. Schmitt J, Buske-Kirschbaum A, Roessner V (2010) Is atopic disease a risk factor for attention-deficit/hyperactivity disorder? A systematic review. Allergy 65:1506-1524

18. Shin KM, Shin YM, Lim KY, Chung YK, Cho S-M (2012) Gender-specific early risk factors for delinquent behavior of Korean youth: A 6- to 8-year longitudinal study. Eur Child Adolesc Psychiatry. doi:10.1007/s00787-012-0306-5

19. Sourander A, Koskelainen M, Niemelä S, Ikonen M, Ristkari T, Lindroos J (2012) Changes in adolescent mental health and use of alcohol and tobacco-a 10-year time-trends study of Finnish adolescents. Eur Child Adolesc Psychiatry. doi:10.1007/s00787012-0303-8

20. Spuij M, Reitz E, Prinzie P, Stikkelbroek Y, de Roos C, Boelen PA (2012) Distinctiveness of Symptoms of Prolonged Grief, Depression, and Posttraumatic Stress in Bereaved Children and Adolescents. Eur Child Adolesc Psychiatry. doi:10.1007/s00787012-0307-4

21. Veen V, Stevens G, Doreleijers T, van der Ende J, Vollebergh W (2010) Ethnic differences in mental health among incarcerated youths: do Moroccan immigrant boys show less psychopathology than native Dutch boys? Eur Child Adolesc Psychiatry 19:431-440

22. Wentz E, Gillberg IC, Anckarsater H, Gillberg C, Rastam M (2012) Somatic problems and self-injurious behaviour 18 years after teenage-onset anorexia nervosa. Eur Child Adolesc Psychiatry $21: 421-432$ 